\title{
Antimicrobial, Cyto and Genotoxic Activities of Equisetum hyemale
}

\author{
Camilla Filippi dos Santos Alves',*, Pauline Cordenonsi Bonez², Marcia de Souza Ebling ${ }^{3}$, Camila Casagrande², \\ Litiane Freitas ${ }^{2}$, Carolina Dolwitsch ${ }^{5}$, Fernanda Pires ${ }^{5}$, Michele Rorato Sagrillo ${ }^{4}$, Gerson Fernandes de Brum ${ }^{4}$, \\ Marli Matiko Anraku de Campos ${ }^{1}$, Roberto Christ Vianna Santos ${ }^{2}$
}

\section{Camilla Filippi dos Santos Alves ${ }^{1, *}$, Pauline Cordenonsi Bonez $^{2}$, Marcia de Souza Ebling ${ }^{3}$, Camila Casagrande ${ }^{2}$, Litiane Freitas $^{2}$, Carolina Dolwitsch ${ }^{5}$, Fernanda Pires ${ }^{5}$, Michele Rorato Sagrillo ${ }^{4}$, Gerson Fernandes de Brum ${ }^{4}$, Marli Matiko Anraku de Campos ${ }^{1}$, Roberto Christ Vianna Santos $^{2}$}

'Department of Clinical and Toxicological Analysis, Mycobacteriology Laboratory, Universidade Federal de Santa Maria (UFSM), Santa Maria, BRAZIL.

${ }^{2}$ Oral Microbiology Research Laboratory,

Microbiology and Parasitology Department,

Universidade Federal de Santa Maria (UFSM), Santa Maria, BRAZIL.

${ }^{3}$ Graduate Program in Nanoscience, Franciscan University (UFN), Santa Maria, RS, BRAZIL.

${ }^{4}$ Cell Culture Laboratory, Universidade Franciscana (UFN), Santa Maria, BRAZIL. ${ }^{5}$ Graduate Program in Pharmaceutical Sciences, Universidade Federal de Santa Maria (UFSM), Santa Maria, BRAZIL.

\section{Correspondence}

\section{M.a Camilla Filippi dos Santos Alves}

Department of Clinical and Toxicological Analysis, Mycobacteriology Laboratory, Universidade Federal de Santa Maria (UFSM), Santa Maria, Brazil. Av. Roraima n 1000 Cidade Universitária, Bairro Camobi, Zip Code: 97105-900, BRAZIL.

E-mail: camillafilippibio@gmail.com

History

- Submission Date: 15-08-2019;

- Review completed: 16-09-2019;

- Accepted Date: 16-09-2019.

\section{DOI : 10.5530/pj.2019.11.239}

Article Available online http://www.phcogj.com/v11/i6s

\section{Copyright}

(C) 2019 Phcogj.Com. This is an open access article distributed under the terms of the Creative Commons Attribution 4.0 International license.

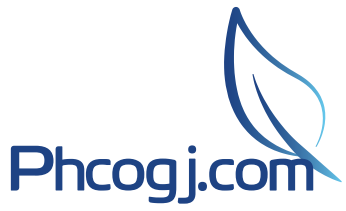

\section{ABSTRACT}

The popular use of natural products has great benefits for the health of the human population In this study we highlight Equisetum hyemale, belonging to the phylum Sphenophyta and the family Equisetaceae. Popularly, the stems of this plant are used for their diuretic, digestive, anti-anemic, and anti-inflammatory properties. Given this context, and the fact that the growth of antimicrobial resistance is a serious problem for global public health, this plant could be used as an alternative, to increase our therapeutic arsenal. Therefore, it is important to more clearly elucidate the complex structures present in plants, because these substances are mainly responsible for their beneficial and/or toxic effects. Thus, the objective of this study was evaluate the antimicrobial activity, cytotoxic and genotoxic potential of the phenolic compounds separately. The substances luteolin, ferulic acid and coumarin were identified at high concentrations by ultra-high performance chromatography-electrospray ionization-mass spectrometry (UPLC-ESI-MS). Antimicrobial activity was elucidated through microdilution in broth; the phenolic compounds were able to inhibit the visible growth of the standard bacterial strains at low concentrations. Cytotoxicity was evaluated by MTT and genotoxicity was analysed through cellular damage using a Comet assay; the results showed that it did not present cytoxicity or genotoxicity at the corresponding concentrations. With this, we suggest that $E$. hyemale may be an alternative for the treatment of infections by microorganisms that are resistant to synthetic drugs.

Key words: Equisetum hyemale. Phenolic compounds. Cytotoxicity. Antimicrobial activity.

\section{INTRODUCTION}

Equisetum hyemale is notable for demonstrating important benefits to human health. Its morphology includes greatly reduced leaves and air fistulous stems, which resemble a ponytail; for this reason, it has received the popular name of horsetail. It belongs to the phylum Sphenophyta and family Equisetaceae. It is an air plant commonly found in tropical and temperate climates. ${ }^{1,2}$ Popularly, the stems of the plant are used for the production of an infusion that acts as a diuretic, digestive, anti-anemic, anti-inflammatory, and antimicrobial, and is also employed to treat gonorrhea, diarrhea, kidney infections, and bladder and eye diseases. ${ }^{3,4}$ Although there are few reports of the antimicrobial activity of $E$. hyemale in the literature, a study carried out by our research group demonstrated the antimicrobial activity of crude extract and fractions, as well as the ability of these extracts to inhibit the formation of biofilm formed by $P$. aeruginosa ( 01$)$. These results were justified by the presence of high levels of phenyl compounds in the plant structure..$^{5-7}$

The phenyl compounds are secondary metabolites produced by plant with the functions of protection and reproduction. These substances have important biological activities and are classified into groups, according to their chemical structure. Among these groups, phenolic compounds are present in a wide range of fruits and vegetables. ${ }^{8,9}$ Their chemical structure is characterized by having a hydroxyl attached directly to an aromatic hydrocarbon group, and exhibit different biological effects, such as antitumor, antioxidant, anti-inflammatory, antiviral and antimicrobial activities. ${ }^{10-13}$

Therefore, the phenyl compounds could be used as an alternative, to increase our therapeutic arsenal, because the disorderly use of antimicrobial drugs is contributing to the growth of micro-organisms that are resistant to treatments; namely, these strains are able to multiply in the presence of antimicrobial concentrations higher than the doses recommended for the treatment of the patient. ${ }^{14-16}$ After the discovery of the first antimicrobial drugs, it was evident that bacteria possessed resistance mechanisms; however, this scenario was livened up with the frequent introduction of new antibiotics. Currently, antibiotic production is greatly reduced and the prevalence of pathogens' resistance to antibiotics has increased, which has become a serious public health problem..$^{17-19}$

In spite of the benefits offered by natural products, there is a need to preserve their integrity and pharmacological chemistry when raw material is transformed into medicine. ${ }^{19,20}$ With this, one should ensure the constancy of the biological action and their 
own safety, as well as enhance the therapeutic potential. In order for this goal to be reached, herbal production requires, necessarily, previous studies concerning the botanical aspects, agronomic, phytochemical, pharmacological, toxicological, analytical methodologies and development technology ${ }^{11,21}$ Given this, the objective of this study was to define the chemical composition of E. hyemale, as well as to assess its antimicrobial activity, cytotoxicity and genotoxicity.

\section{MATERIALS AND METHODS}

\section{Plant sample collection}

The plant material used in the study was collected in Santa Maria (Rio Grande do Sul, Brazil) in the district of São Martinho da Serra $\left(29^{\circ} 32^{\prime}\right.$ $\left.16^{\prime \prime} \mathrm{S}, 53^{\circ} 51^{\prime} 18^{\prime \prime} \mathrm{W}\right)$, between September and November 2017. The dried specimen is preserved in the herbarium at the Department of Environmental Engineering, Federal University of Santa Maria (UFSM), under register number SMBD 6756. The compounds luteolin, ferulic acid, coumarin and routin were commercially disclosed by Sigma-Aldrich :

\section{Preparation of plant extracts}

The plant stems were dried in a stove (temperature $<40{ }^{\circ} \mathrm{C}$ ) and chopped using a knife mill. The obtained material was macerated at room temperature with $70 \%$ ethanol for one week, with one daily shakeup, and the solvent was renewed for 4 weeks. After filtration, the hydroalcoholic extract was evaporated under reduced pressure in a rotary evaporator to remove the ethanol, thereby obtaining an aqueous extract. Part of the aqueous extract was dried in a stove (temperature above $40^{\circ} \mathrm{C}$ ) to obtain the crude extract (CE). After that, the remaining aqueous extract was partitioned with dichloromethane (DCM), ethyl acetate (EA) and n-butanol (NB), successively. ${ }^{10}$

\section{Preparation of solid-phase extraction (SPE)}

Firstly, $3 \mathrm{~mL}$ of the diluted extract was added to $12 \mathrm{~mL}$ of ultrapure water (1:4). Then, $15 \mu \mathrm{L}$ of the acetic acid was added, producing a final proportion of $0.1 \%(\mathrm{v} / \mathrm{v})$. From the SPE cartridges of Strata C-18E, $500 \mathrm{mg}$ was used, with a capacity of $3 \mathrm{~mL}$ (Phenomenex, Torrance, USA). The cartridges went through a conditioning stage with $6 \mathrm{~mL}$ of $0.2 \%(1: 1 ; \mathrm{v} / \mathrm{v})$ methanol/acetic acid, then with $6 \mathrm{~mL}$ of $0.1 \%(\mathrm{v} / \mathrm{v})$ acetic acid solution in water. After obtaining a fixed volume of $2 \mathrm{~mL}$ of the extracts, with a composition ethanol/water/acetic acid (20:80:0.1; $\mathrm{v} / \mathrm{v})$, the solution was percolated to a leak of $2 \mathrm{~mL} \mathrm{~min}^{-1}$, followed by a washing with $2 \mathrm{~mL}$ of $0.1 \%(\mathrm{v} / \mathrm{v})$ acetic acid solution. Finally, the removed analytes were eluted with $2 \mathrm{~mL}$ of $\mathrm{MeOH}$. Just prior to the chromatographic analysis, the eluate obtained by the SPE procedure was diluted to $0.5 \mathrm{~g} \mathrm{~L}^{-1}$ with $0.1 \%(1: 1 ; \mathrm{v} / \mathrm{v})$ methanol/acetic acid solution. ${ }^{22}$

Ultra high performance chromatography-electrospray ionization-mass spectrometry (UPLC-ESI-MS)

Analysis was performed according to Faccin and collaborators (2016), at the Research Center and Analysis of Contaminant Residues of the UFSM. The UPLC-ESI-MS system consists of a chromatograph (ACQUITY UPLC) coupled to a mass spectrometer (XEVO TQ-S triploquadrupolo), Milford, USA). The column C18 Acquity UPLC BEH $(100 \mathrm{~mm}$, i.d. $2.1 \mu \mathrm{m}$, particle $1.7 \mu \mathrm{m}$; Waters $)$ was used, and maintained under heat at $40{ }^{\circ} \mathrm{C}$. The method uses a gradient elution, containing $0.1 \%$ acetic acid (A) and acetonitrile (B), at a constant flow rate of $800 \mu \mathrm{L} \cdot \mathrm{min}^{-1}$, according to the following conditions: $8.0 \% \mathrm{~B}$ (0.00-0.10 min); 8.0-25.8\% B (0.10-3.45 min); 25.8-54.0\% B (3.45-6.90 $\mathrm{min}) ; 54.0-100.0 \%$ B (6.90-7.00 $\mathrm{min}) ; 100.0 \%$ B (7.00-9.00 $\mathrm{min})$; and an injection volume of $5 \mu$ l. The mass spectrometer was operated using the negative electrospray ESI (-) ionization mode, with the following parameters: gas flow (N2) at $11 \mathrm{~L} \mathrm{~min}^{-1}$; nebulizer pressure equal to 30 psi; capillary voltage equal to $\pm 2.4 \mathrm{kV}$ and during gas temperature equal to $250^{\circ} \mathrm{C}$. The comps were analyzed in a mass spectrometer operating under "multiple reaction monitoring" (MRM). The analyzed data were acquired using quantitative analysis using the MassLynx Mass Spectrometry software (Waters).

\section{Preparation of inoculums}

The bacterial inoculum sizes were standardized according to Clinical and Laboratory Standards Institute standards (CLSI). The bacterial strains American Type Culture Collection (ATCC) E. faecalis (ATCC 29212), S. epidermidis (ATCC 35985), S. saprophyticus (ATCC 15305), S. aureus (ATCC 33691), MRSA-IC (clinical isolate of methicillinresistant Staphylococcus aureus), L. monocytogenes (ATCC 7644), E. coli (ATCC 25922), S. enteritidis (ATCC13076), S. flexineri (ATCC 12022323), P. aeruginosa (ATCC 27853), P. aeruginosa PA01, and K. pneumoniae (ATCC 1705) were used. Isolated colonies were grown for 18 and $24 \mathrm{~h}$ in Mueller-Hinton agar (Himedia, India) and the suspension was prepared in saline solution $(0.85 \%)$ with $\mathrm{NaCl}$ density adjusted to 0.5 on the McFarland scale $\left(1.5 \times 10^{8} \mathrm{CFU} / \mathrm{mL}\right) .{ }^{23}$

\section{Determination of minimum inhibitory concentration (MIC)}

The antibacterial activity, according to Clinical and Laboratory Standards Institute standards, of the phenolic compounds was evaluated using the broth microdilution method. The assay was carried out in 96well microtiter plates using Mueller-Hinton broth (Himedia ${ }^{\circ}$ ). Each extract was diluted in dimethyl sulfoxide (DMSO) and gave rise to serial concentrations ranging from 2 to $0.185 \mu \mathrm{g} / \mathrm{mL}$ (initial concentrations of the tests for the phenolic compounds were established from the equivalent concentrations identified in the extracts). The inoculum was mixed in the dilution of compounds. The plates were incubated at $37^{\circ} \mathrm{C}$ and the minimal inhibitory concentration (MIC) was recorded after 24 $\mathrm{h}$ of incubation. The MICs were defined as the lowest concentration of extract that inhibited visible bacterial growth. This test was performed in triplicate, and 2, 3,5-triphenyltetrazolium chloride was used as an indicator of microbial growth. A positive control growth culture medium and microorganism were used. For the control of sterility, only culture medium was used for negative growth. In the same way, a control of the solvent DMSO was carried out at the same concentration used for the dilution of the samples. ${ }^{23}$

\section{Mononuclear cells}

Blood was collected for toxicological tests. Peripheral blood samples were obtained through three discarded samples from the Laboratory of Clinical Analysis of the University Franciscan, under the approval of the Institution's Ethics Committee on Human Beings (CAAE: 31211214.4 .0000.5306), with the absence of identification data. The samples were obtained through venipuncture using tubes with Vacutainer-type heparin, which were used to separate PBMCs and the subsequent treatments and cell cultures. ${ }^{24}$

\section{Evaluation of cell viability by the MTT technique}

In the MTT assay, the 3- [4,5-dimethyl-thiazol-2-yl] -2,5-diphenyltetrazolium bromide reagent is water-soluble and yellowish in color, being readily incorporated by viable cells, which reduce this compound's mitochondrial activity by the enzyme succinate dehydrogenase. Upon being reduced, MTT is converted into formazan crystals, which are insoluble in water and bluish-purple in color and stored in the cell cytoplasm, and subsequently solubilized by the addition of DMSO (dimethyl sulfoxide); they were quantified calorimetrically by spectrophotometry over a $570 \mathrm{~nm}$ wave. Curves with different concentrations were calculated from the MIC values for both the extracts [14] and the compounds; these concentrations were 
added to the cell cultures. The absorbance value is proportional to the number of viable cells, in comparison to the negative control. ${ }^{24,25}$

\section{Genotoxicity evaluation}

The genotoxicity evaluation was performed by a Comet assay. The cells were treated with different concentrations, which varied between $3 \mu \mathrm{g} /$ $\mathrm{mL}$ and $300 \mu \mathrm{g} / \mathrm{mL}$ for the crude extract and fractions, and $2 \mu \mathrm{g} / \mathrm{mL}$ and $10 \mu \mathrm{g} / \mathrm{mL}$ for the phenolic compounds. These concentration ranges were defined on the basis of the minimum inhibitory concentrations (MICs) obtained in our first published study. The concentration were suspended in low-melting agarose (deposited on a glass slide precoated with a layer of $1.5 \%$ agarose). The material was immersed in lysis solution (lysis solution: 89 and $10 \mathrm{~mL}$ of dimethyl sulfoxide and $1 \mathrm{~mL}$ of Triton X-100) for the removal of the membranes and cytoplasm. Subsequently, the slides were incubated in alkaline electrophoresis buffer at a $\mathrm{pH}$ of $13\left(300 \mathrm{mmol} \mathrm{L}^{-1} \mathrm{NaOH}\right.$ and $1 \mathrm{mmol} \mathrm{L}^{-1}$ EDTA in distilled water) and subjected to electrophoresis for $30 \mathrm{~min}$ at $25 \mathrm{~V}$ and $300 \mathrm{~mA}$. Then, the processes of neutralization (neutralizing buffer $\mathrm{pH}$ 7.5), fixation (15\% trichloroacetic acid) and coloration (acridine orange) were performed, so that the genetic material could be analyzed. One hundred cells were analyzed in an optical microscope and were classified according to their tail length. The cells received scores from 0 (no damage) to 4 (maximum damage). The test was performed in triplicate, and the data were transformed into a damage index, which was analysed statistically. The genotoxic potential was measured $48 \mathrm{~h}$ after exposure to the extracts and compound; they were considered genotoxic when the concentrations resulted in a damage index higher that $0.1 .^{25}$

\section{Statistical analysis}

OD readings obtained from the assay were recorded as mean + SE and were submitted to a one-way ANOVA. A $p$ value $\geq 0.05$ was considered to indicate statistical significance. Graphs were prepared using GraphPad Prism version 5.01 (GraphPad Software, La Jolla, CA).

\section{RESULTS AND DISCUSSION}

\section{Phytochemical characterization by UPLC-ESI-MS}

The major crude extract (CE) compounds found using the UPLC-ESIMS system included luteolin (LUT; $3.7 \mu \mathrm{g} / \mathrm{mL}$ ) and ferulic acid (FA; $1.7 \mu \mathrm{g} \mathrm{mL}$ ) ) (Figure 1a), where as in the ethyl acetate (AE) fractions, coumarin $(\mathrm{CM} ; 2.06 \mu \mathrm{g} / \mathrm{mL})$ and ferulic acid $(\mathrm{FA} ; 3.8 \mu \mathrm{g} / \mathrm{mL})$ stood out (Figure 1b). The main components of the dichloromethane (DCM) (Figure 1c). and butanol (NB) fraction (Figure 1d) were ferulic acid (FA; $3.5 \mu \mathrm{g} / \mathrm{mL}$ and $1.5 \mu \mathrm{g} / \mathrm{mL}$, respectively) and routin (RUT; $2.8 \mu \mathrm{g} /$ $\mathrm{mL}$ and $1.7 \mu \mathrm{g} / \mathrm{mL}$ ) respectively.

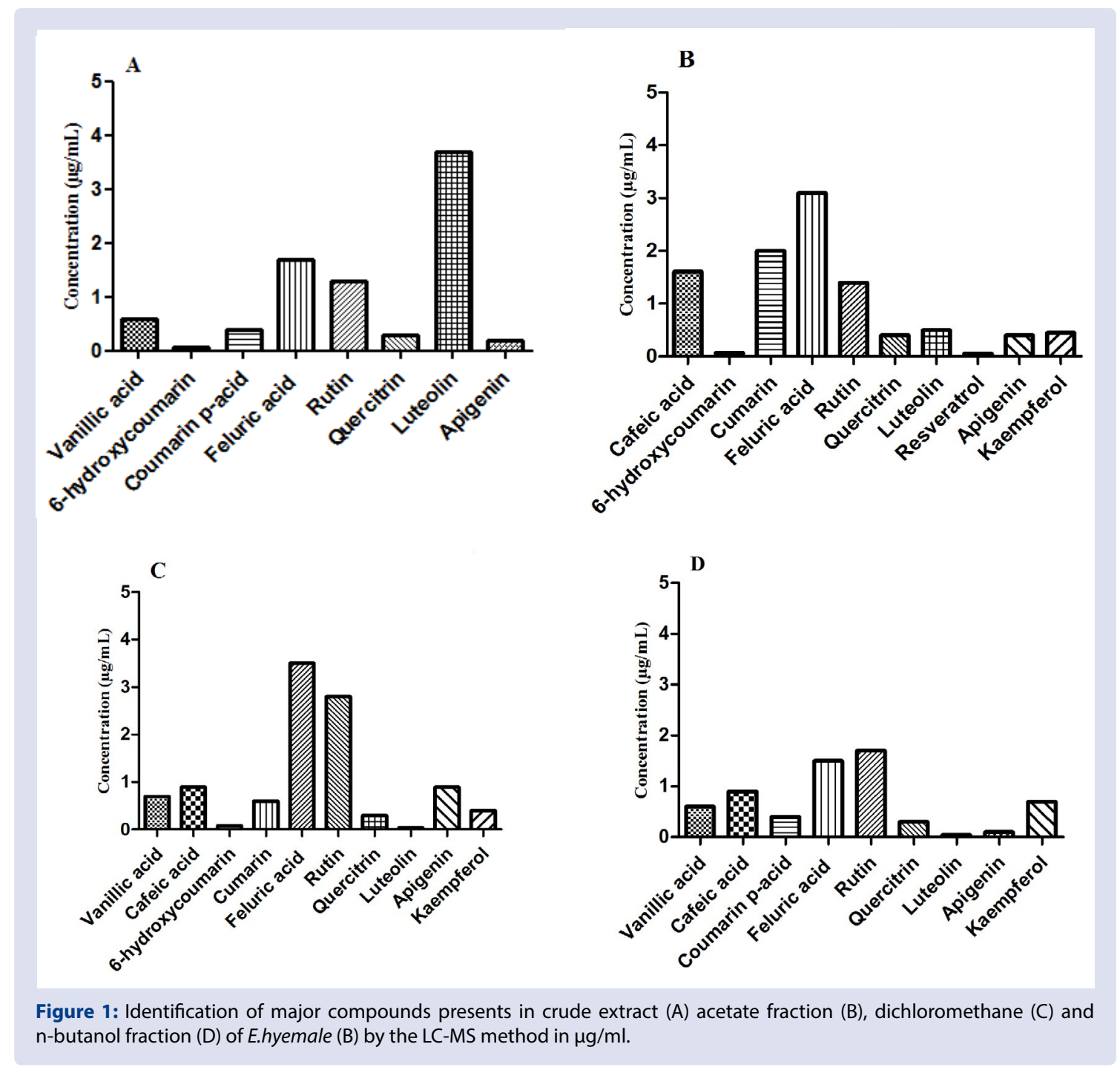


These substances are part of the phenol compounds group and the antimicrobial activity this compounds is often reported in the literature. Luteolin has a potent antimicrobial action and can operate via different mechanisms of action, such as the inhibition of the production of proteins and peptidoglycan, the alteration of the permeability of the internal membrane of the microorganism, and inhibition. ${ }^{26,27}$ In the same way, ferulic acid has been shown to have moderate antimicrobial activity. ${ }^{28,29}$ The for coumarin, this action is attributed to its lipophilic chemical structure, since the presence of hydroxyl groups and the size of the carbon chain facilitate their entry into the microbial cell. ${ }^{30}$ One study has made it clear that routin acts in synergy with other phenolic compounds, potentiating the antimicrobial activity of phytochemicals. ${ }^{31}$ All of these studies corroborate with the results obtained in our research, since we observed that the major substances of $E$. hyemale have significant antimicrobial activity alone and in adjusted concentrations at the values identified in the crude extract and fractions of the plant.

\section{Antimicrobial activity}

We calculated the identified relative values of each major substance present in the crude extract and fractions, and we evaluated the activity of these substances alone. The results showed that the phenolic compounds were able to inhibit the visible growth of the S. epidermidis ATCC 35985, S. saprophyticus ATCC 15305, S. aureus ATCC 33691, MRSA-IC (clinical isolate of methicillin-resistant Staphylococcus aureus), E. coli ATCC 25922, S. enteritidis ATCC 13076, S. flexineri ATCC 12022323a , P. aeruginosa ATCC 27853, P. aeruginosa PA01, K. pneumoniae ATCC 1705, E. faecalis ATCC 29212 and L. monocytogenes ATCC 7644. The MIC values were low and satisfactory, with concentrations ranging from $0.37 \mu \mathrm{g} / \mathrm{mL}$ at $0.75 \mu \mathrm{g} /$ $\mathrm{mL}$ MIC, as shown in Table 1.

In a previous study carried out by our research group, we demonstrated that crude extracts, the dichloromethane fraction, acetate fraction and N-butanol fraction of E. hyemale showed antimicrobial activity against S. epidermidis ATCC 35985, S. saprophyticus ATCC 15305, S. aureus ATCC 33691, MRSA-IC (clinical isolate of methicillin-resistant Staphylococcus aureus), E. coli ATCC 25922, S. enteritidis ATCC 13076, S. flexineri ATCC 12022323a, P. aeruginosa ATCC 27853, P. aeruginosa PA01, K. pneumoniae ATCC 1705, E. faecalis ATCC 29212 and L. monocytogenes ATCC 7644, with minimal inhibitory concentrations (MIC) ranging from 3.270 at $5.2410 \mu \mathrm{g} / \mathrm{mL}^{7}$ Therefore, in this study, we clearly identify the presence of the major substances in the crude extract and fractions previously analyzed (routin, coumarin, ferulic acid and luteolin).

\section{Safety of using}

In order to prove the safety of using E. hyemale, we performed a cytotoxicity and genotoxicity test in vitro. The crude extracts, fractions and phenolic compounds were able to maintain cell viability at all exposure times, and the concentration values used were adjusted with the value obtained for the MIC (Figure 2). Similarly, in the comet assay shown in Figure 3, the low obtained damage rates show that the extracts and compounds did not damage the genetic material of the cells.

The presence of high levels of phenol compounds in the Equisetum genus have been demonstrated in the literature. ${ }^{4,32-36}$. Therefore, few studies have evaluated the biological and toxicology activities of these substances alone. The results obtained in this study suggest that phenolic compounds were mainly responsible for the biological activities of the plant. ${ }^{32,37}$.

Although these plants are beneficial for health human, high doses may present toxic and deleterious effects. ${ }^{38,39}$ Most people still use this vegetable without previous knowledge of the composition of the products. ${ }^{40}$ Other studies report that, in the presence of metals and in high concentrations, phenolic compounds have pro-oxidant activity and can cause cellular damage. ${ }^{41}$ When the hydro-alcoholic extracts of five Equisetum species (E. arvense, E. sylvaticum, E. fluviatile, E. palustre and E. telmateia Ehrh) were evaluated for their genotoxicity, the results showed that high concentrations induce cellular damage. ${ }^{42}$ However, another study noted that the phytoextract of the genus Equisetum did not induce acute toxicity in Drosophila or in human lymphocytes in culture, at low concentrations. ${ }^{43}$

\section{CONCLUSION}

Given this, we conclude it is extremely important that, along with studies of the biological activities of plants, evaluations of the cytotoxicity and genotoxicity of these plants should be conducted, in order to offer greater safety to humans. Equisetum hyemale has the potential for antimicrobial activity and does not show cytotoxic and

Table 1: Antibacterial activity of compounds phenolics identified in crude extract and fractions of E. hyemale against strains bacterial standards.

\begin{tabular}{lcccc}
\hline & \multicolumn{4}{c}{$\mathrm{MIC}(\mu \mathrm{g} / \mathrm{mL})$} \\
\hline & AF & LT & CM & RUT \\
\hline E. faecalis ATCC 29212 & 0,75 & 0,37 & 0,75 & 0,75 \\
S. epidermidis ATCC 35985 & 0,75 & 0,37 & 0,75 & 0,75 \\
S. saprophyticus ATCC 15305 & 0,75 & 0,75 & 0,75 & 0,75 \\
S. aureus ATCC 33691 & 0,37 & 0,37 & 0,37 & 0,37 \\
MRSA-IC & 0,75 & 0,75 & 0,75 & 0,75 \\
L. monocytogenes ATCC 7644 & 0,75 & 0,18 & 0,75 & 0,75 \\
E. coli ATCC 25922 & - & 0,75 & 0,75 & 0,75 \\
S. enteritidis ATCC 13076 & - & 0,75 & 0,75 & - \\
S. flexineri ATCC 12022323 & 0,75 & 0,37 & 0,75 & 0,75 \\
P. aeruginosa ATCC 27853 & 0,75 & 0,37 & 0,75 & 0,75 \\
P. aeruginosa PA01 & 0,75 & 0,37 & 0,75 & 0,75 \\
K. pneumoniae ATCC 1705 & 0,75 & 0,37 & 0,75 & 0,75 \\
\hline
\end{tabular}

Minimal Inhibitory Concentration; ATCC: American Type Culture Collection; AF: Ferulic acid; LT: Luteolin; CM: Coumarin; RUT: Routin. 

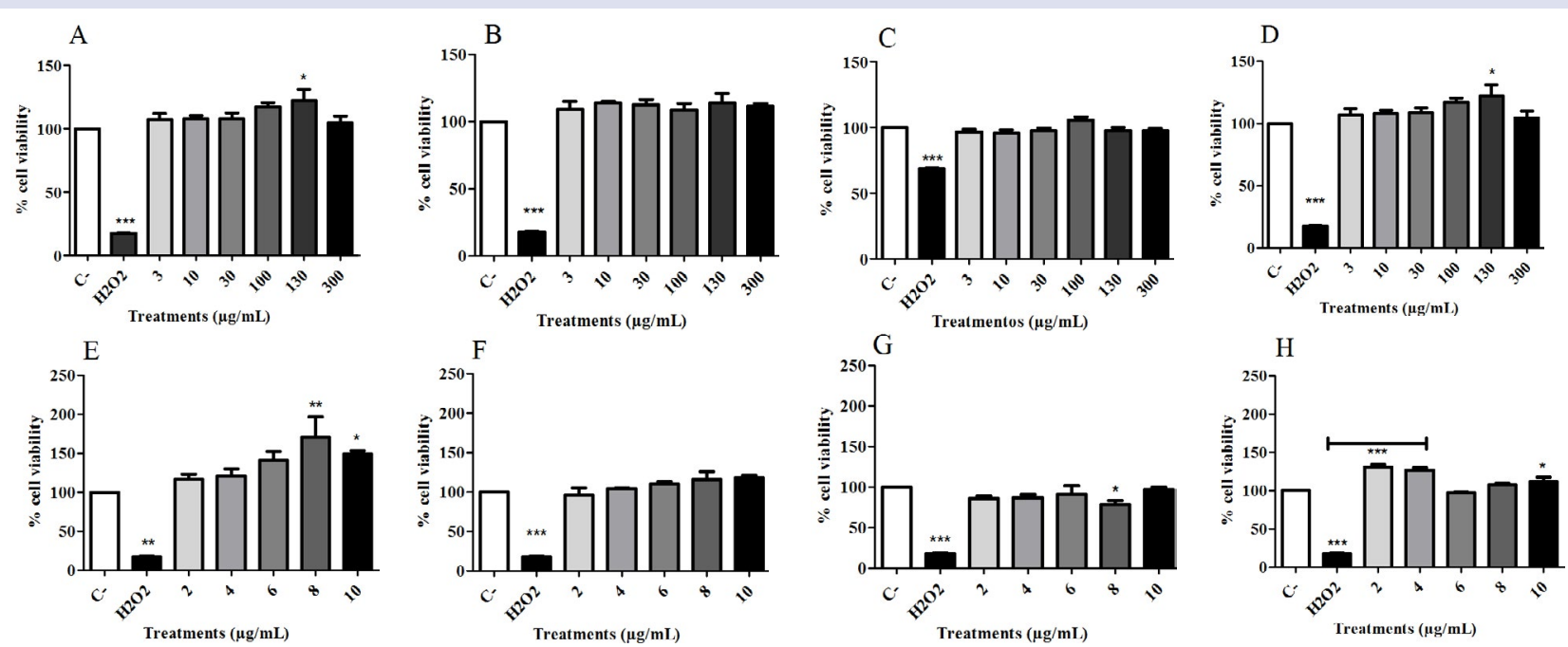

Figure 2: Comparison of cytotoxicity evaluated by MTT reduction in mononuclear cells exposed to $\mathrm{H}_{2} \mathrm{O}_{2}$ and treated with crude extract, fractions and major compounds of $E$. hyemale. Extract crude (A), acetate fraction (B), Dichloromethane fraction (C), N-butanol fraction (D), Luteolin (E), Ferulic acid $(F)$, Coumarin $(G)$ and Routin $(H)$. Results were expressed as percentage of the negative control $(100 \%)$.
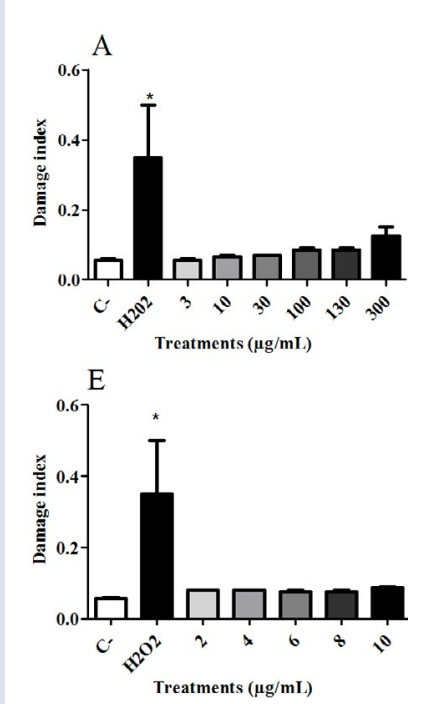
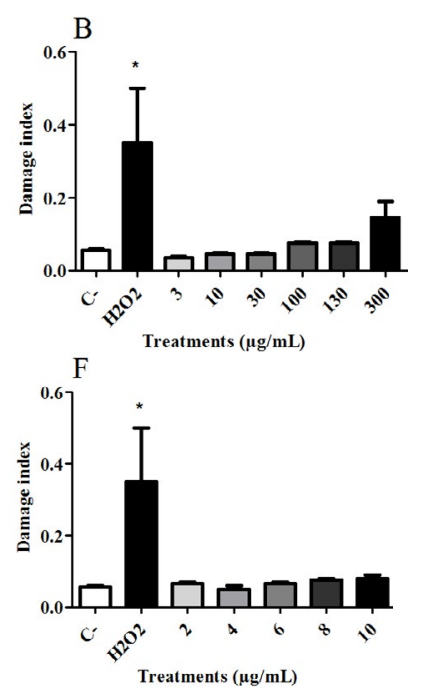
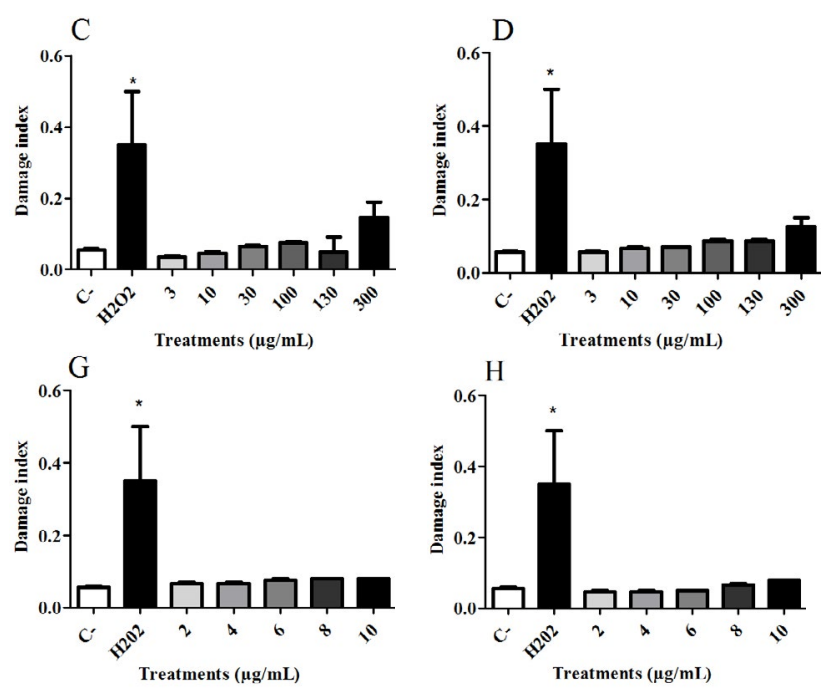

Figure 3: DNA migration in the comet assay for assessment of genotoxicity of crude extract, frations and major compounds of E. hyemale exposed to peripheral blood mononuclear cell culture for $72 \mathrm{~h}$. Extract crude (A), acetate fraction (B), Dichloromethane fraction (C), N- butanol fraction (D), Luteolin (E), Ferulic acid (F), Coumarin (G) and Routin (H).

genotoxic effects. Therefore, this plant may be an alternative treatment for microbial infections; these activities are attributed to the presence of phenolic compounds in the plant. From these results, studies can be carried out using models of infection in experimental animals that, in turn, will redefine the basis for therapeutic studies in humans.

\section{CONFLICTS OF INTEREST}

The authors declare that they have no conflicts of interest.

\section{ACKNOWLEDGMENTS}

This work was financially supported by FAPERGS, CNPq and CAPES.

\section{REFERENCES}

1. Brune T, Thiv M, Haas K. Equisetum (Equisetaceae) species or hybrids? ISSR fingerprinting profiles help improve diagnoses based on morphology and anatomy. Plant Systematics and Evolution. 2008;274(1-2):67-81.
2. Sapei L, Gierlinger N, Hartmann J, Nöske R, Strauch P, Paris O. Structural and analytical studies of silica accumulations in equisetum hyemale. Analytical and Bioanalytical Chemistry. 2007;389(4):1249-57.

3. Yamanaka S, Sato K, Ito F, Komatsubara S, Ohata H, Yoshino K. Roles of silica and lignin in horsetail (Equisetum Hyemale), with special reference to mechanical properties. Journal of Applied Physics. 2012;111(4).

4. Gierler N, Sapei L, Paris O. Insights into the chemical composition of equisetum hyemale by high resolution raman imaging. Planta. 2008;227(5):969-80.

5. Ferrazzano GF, Roberto L, Catania MR, Chiaviello A, De Natale A, Roscetto E, et al. Screening and scoring of antimicrobial and biological activities of italian vulnerary plants against major oral pathogenic bacteria. Evidence-based Complementary and Alternative Medicine. 2013.

6. de Queiroz GM, Politi FAS, Rodrigues ER, Souza-Moreira TM, Moreira RRD, Cardoso CRP, et al. Phytochemical characterization, antimicrobial activity, and antioxidant potential of Equisetum Hyemale L. (Equisetaceae) extracts. Journal of Medicinal Food. 2015;18(7):830-4.

7. dos Santos Alves CF, Bonez PC, de Souza M de E, da Cruz RC, Boligon AA, Piana $M$, et al. Antimicrobial, antitrypanosomal and antibiofilm activity of equisetum hyemale. Microbial Pathogenesis. 2016;101:119-25. 
8. Piana M, De Brum TF, Boligon AA, Alves CFS, De Freitas RB, Nunes LT, et al. In vitro growth-inhibitory effect of brazilian plants extracts against paenibacillus larvae and toxicity in bees. Anais da Academia Brasileira de Ciencias. 2015;87(2):1041-7.

9. Corrêa R, Agertt V, Boligon AA. Natural product research : Formerly natural product letters in vitro antimycobacterial activity and HPLC - DAD screening of phenolics from Ficus Benjamina L . and Ficus Luschnathiana (Miq .) Miq . Leaves. 2012;37-41.

10. Boligon AA, Piana $M$, de Brum TF, de Freitas RB, Nunes $L$, Pappis $L$, et al. Potential use of buddleja thyrsoides for the control and prevention of american foulbrood disease in honey bees. Journal of Apicultural Science. 2014;58(2):718.

11. Corcoran MP, McKay DL, Blumberg JB. Flavonoid basics: Chemistry, sources, mechanisms of action, and safety. Journal of Nutrition in Gerontology and Geriatrics. 2012.

12. Witaicenis A, Seito LN, Di Stasi LC. Intestinal anti-inflammatory activity of esculetin and 4-methylesculetin in the trinitrobenzenesulphonic acid model of rat colitis. Chemico-Biological Interactions. 2010.

13. Khan MTH, Ather A, Thompson KD, Gambari R. Extracts and molecules from medicinal plants against herpes simplex viruses. Antiviral Research. 2005.

14. Center for disease control and prevention. Antibiotic/ antimicrobial resistance CDC. Center for Disease Control and Prevention. 2015.

15. Hirsch EB, Tam VH. Impact of multidrug-resistant pseudomonas aeruginosa infection on patient outcomes. Expert Review of Pharmacoeconomics and Outcomes Research. 2010;10(4):441-51.

16. Friedrich K, Nüssle $S$, Rehlen T, Stremmel W, Mischnik A, Eisenbach C. Microbiology and resistence in first episodes of spontaneous bacterial peritonitis: Implications for management and prognosis. Journal of Gastroenterology and Hepatology. 2016.

17. Wannmacher L. Uso Indiscriminado de Antibióticos e Resistência Microbiana: Uma Guerra Perdida? 2004;1(4);1-5.

18. Bilal M, RasheedT, Iqbal HMN, Hu H, Wang W, Zhang X. Macromolecular agents with antimicrobial potentialities: A drive to combat antimicrobial resistance. International Journal of Biological Macromolecules. 2017;103;554-74.

19. Patrick GL. An introduction to medicinal chemistry. UCL Lecture Notes. 2009.

20. Martin C, Zhang Y, Tonelli C, Petroni K. Plants, diet, and health. Annual Review of Plant Biology. 2013.

21. Han X, Li Z, Li CY, Jia WN, Wang HT, Wang CH. Phytochemical constituents and biological activities of plants from the genus dryopteris. 2015;12.

22. Faccin H, Viana C, do Nascimento PC, Bohrer D, de Carvalho LM. Study of ion suppression for phenolic compounds in medicinal plant extracts using liquid chromatography-electrospray tandem mass spectrometry. Journal of Chromatography A. 2016;1427:111-24

23. CLSI. Performance Standards for Antimicrobial Susceptibility Testing. 27th Ed. CLSI Supplement M100. Wayne, PA: Clinical and Laboratory Standards Institute; 2017

24. Sagrillo MR, Garcia LFM, De Souza Filho OC, Duarte MMMF, Ribeiro EE, Cadoná $F C$, et al. Tucumã fruit extracts (Astrocaryum Aculeatum Meyer) decrease cytotoxic effects of hydrogen peroxide on human lymphocytes. Food Chemistry. 2015;173:741-8.

25. Bonez PC, Ramos AP, Nascimento K, Copetti PM, Souza ME, Rossi GG, et al. Antibacterial, cyto and genotoxic activities of a22 compound (IS3, 4 -Dichlorobenzyl) Isothiourea Hydrochloride). Microbial Pathogenesis. 2016;99:14-8.
26. Eumkeb G, Siriwong S, Thumanu K. Synergistic activity of luteolin and amoxicillin combination against amoxicillin-resistant Escherichia Coli and mode of action. Journal of Photochemistry and Photobiology B: Biology. 2012;117:247-53.

27. Lou Z, Tang $Y$, Song $X$, Wang $H$. Metabolomics-based screening of biofilminhibitory compounds against pseudomonas aeruginosa from burdock leaf. Molecules. 2015;20(9), 16266-77.

28. Ben Yakoub AR, Abdehedi O, Jridi M, Elfalleh W, Nasri M, Ferchichi A Flavonoids, phenols, antioxidant, and antimicrobial activities in various extracts from tossa jute leave (Corchorus Olitorus L.). Industrial Crops and Products. 2018;118:206-13.

29. Kumar N, Pruthi V. Potential applications of ferulic acid from natural sources. Biotechnology Reports. 2014;4(1);86-93.

30. Zhu JJ, Jiang JG. Pharmacological and nutritional effects of natural coumarins and their structure-activity relationships. Molecular Nutrition \& Food Research. 2018;e1701073.

31. Arima $H$, Ashida $H$, Danno G. Rutin-enhanced antibacterial activities of flavonoids against Bacillus Cereus and Salmonella Enteritidis. Bioscience, Biotechnology, and Biochemistry. 2002;66(5):1009-14.

32. Kukric Z, Topalic-Trivunovic L, Pavicic S, Zabic M, Matos S, Davidovic A. Total phenolic content, antioxidant and antimicrobial activity of Equisetum Arvense L. Chemical Industry and Chemical Engineering Quarterly. 2013;19(1):37-43.

33. Francescato LN, Debenedetti SL, Schwanz TG, Bassani VL, Henriques AT. Identification of phenolic compounds in Equisetum Giganteum by LC-ESI-MS/ MS and a new approach to total flavonoid quantification. Talanta. 2013;105:192 203.

34. Brune T, Haas K. Equisetum Species show uniform epicuticular wax structures but diverse composition patterns. AoB Plants. 2011;11(1):1-14.

35. Garcia D, Ramos AJ, Sanchis V, Marín S. Equisetum Arvense hydro-alcoholic extract: Phenolic composition and antifungal and antimycotoxigenic effect against Aspergillus Flavus and Fusarium Verticillioides in stored maize. Journal of the Science of Food and Agriculture. 2013;93(9):2248-53.

36. Park BJ, Tomohiko M, Feruloyl. Caffeoyl and flavonol glucosides from equisetum hyemale. Chemistry of Natural Compounds. 2011;47(3):363-5.

37. de Oliveira JR, de Castro VC, Vilela P, das GF, Camargo SEA, Carvalho CAT, et al Cytotoxicity of Brazilian plant extracts against oral microorganisms of interest to dentistry. BMC Complementary and Alternative Medicine. 2013;13.

38. Barceloux DG. Medical toxicology of natural substances. Hoboken: John Wiley \& Sons. 2008.

39. Jobim ML, Santos RCV, dos Santos Alves CF, Oliveira RM, Mostardeiro CP Sagrillo MR, et al. Antimicrobial activity of amazon astrocaryum aculeatum extracts and its association to oxidative metabolism. Microbiological Research. 2014;169(4):314-23.

40. Margină D, Ilie M, Grădinaru D, Androutsopoulos VP, Kouretas D, Tsatsakis AM Natural products-friends or foes? Toxicology Letters. 2015;236(3);154-67.

41. Fraga CG, Galleano M, Verstraeten SV, Oteiza PI. Basic biochemical mechanisms behind the health benefits of polyphenols. Molecular Aspects of Medicine. 2010.

42. Spatz HC, Emanns A. The mechanical role of the endodermis in equisetum plant stems. American Journal of Botany. 2004;91(11);1936-8.

43. Quevedo G, Horacio B, Casta N. A phytotherapeutic extract of equisetum myriochaetum is not genotoxic either in the in vivo wing somatic test of drosophila or in the in vitro human micronucleus test. 2007;111:182-9. 


\section{GRAPHICAL ABSTRACT}

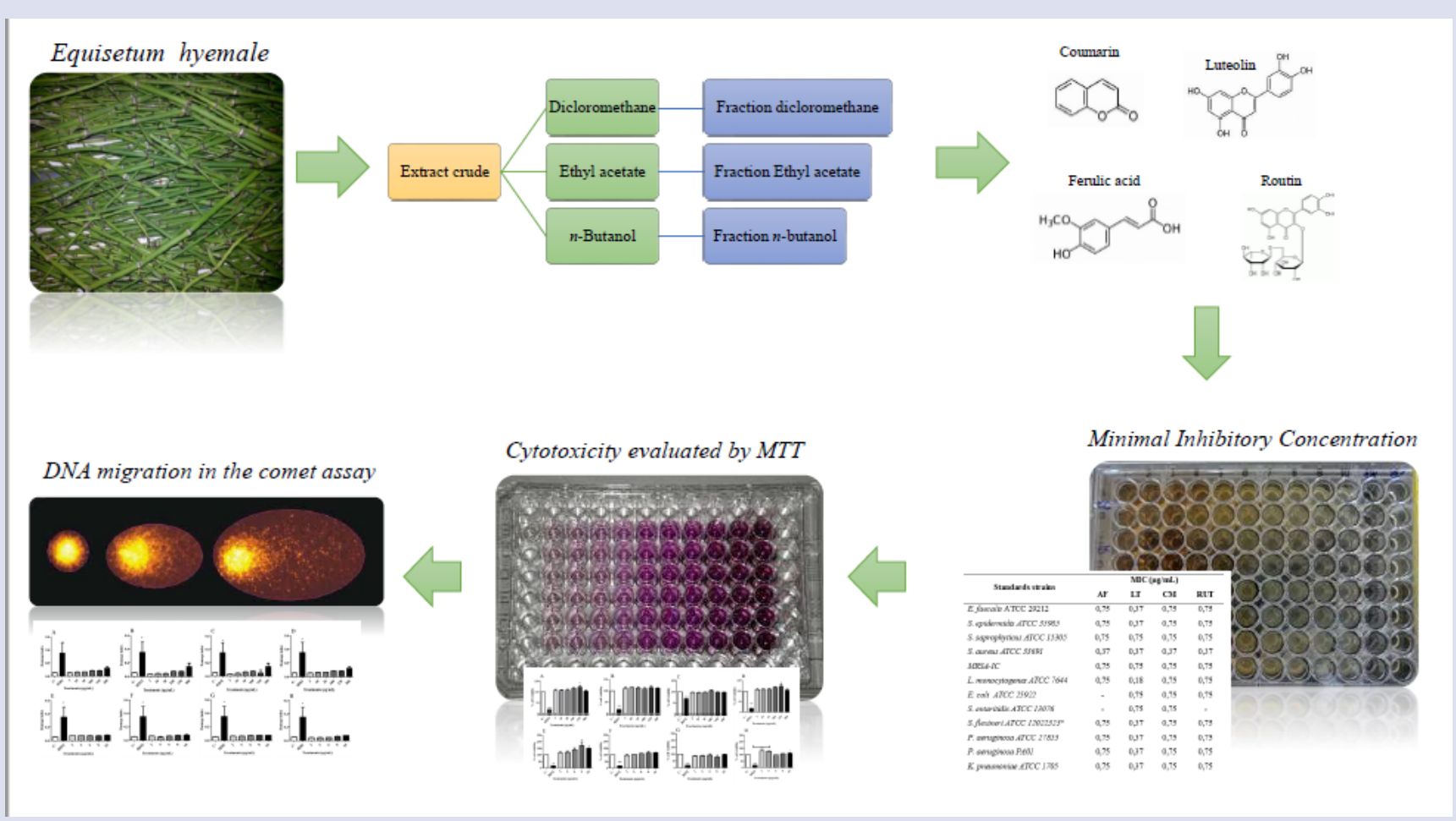

\section{ABOUT AUTHORS}

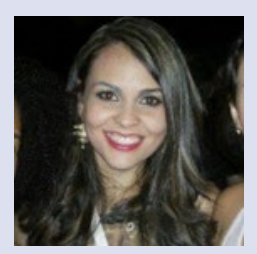

Camilla Filippi dos Santos Alves

Email: camillafilippibio@gmail.com

Corresponding author, holds a degree in Biomedicine from the Franciscan University (2013) and a master's degree in Pharmaceutical Science and Technology from the Federal University of Santa Maria (2015). She is currently a doctoral student at the Federal University of Santa Maria.

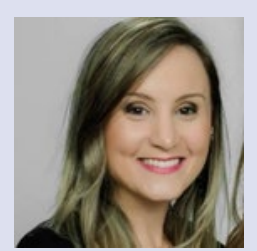

\section{Pauline Cordenonsi Bonez}

Email: pauline-cb@hotmail.com

Participation in microbiological tests and article preparation. Pharmacist (UFSM), Masters and Doctorate in Pharmaceutical Sciences from the Postgraduate Program in Pharmaceutical Sciences (PPGCF) from UFSM. She is currently a postdoctoral student at PPGCF and a professor at the Regional Integrated University of Upper Uruguay and Missions, Santiago-RS campus (URI-Santiago).

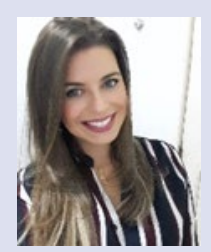

\section{Marcia de Souza Ebling}

\section{Email: marciaeblings@gmail.com}

Participation in microbiological tests and article preparation. Pharmaceutical (UFN) Master in Nanosciences (2014). PhD in Nanosciences (2018) from the Franciscan University Center, CAPES scholarship holder.

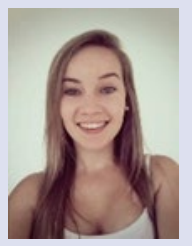

\section{Camila Casagrande}

\section{Email: Cami.casagrande@ hotmail.com}

Participation in microbiological assays. Student of the Pharmacy course at the Federal University of Santa Maria, Scientific Initiation Scholar at the Laboratory of Microbiological Research (LAPEMICRO), under the guidance of Professor Dr. Roberto Christ Vianna Santos. 


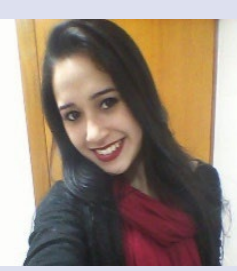

\section{Litiane Freitas}

\section{Email: lithy.freitas@hotmail.com}

Participation in microbiological assays. Student of the Pharmacy course at the Federal University of Santa Maria, Scientific Initiation Scholar at the Laboratory of Microbiological Research (LAPEMICRO), under the guidance of Professor Dr. Roberto Christ Vianna Santos.

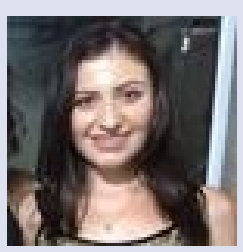

\section{Carolina Dolwitsch}

\section{Email : caroldol@gmail.com}

Participation in chromatographic assays. She holds a degree in Industrial Chemistry from the Federal University of Santa Maria (2012) and a master's degree in Pharmaceutical Sciences from the Federal University of Santa Maria (2015). She is currently a PhD student in Pharmaceutical Sciences and an academic course in Pharmacy at the Federal University of Santa Maria.

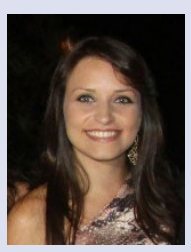

\section{Fernanda Pires}

\section{Email: fernandabrumpires@gmail.com}

Participation in chromatographic assays. Graduated in Pharmacy with generalist training from the Franciscan University Center- UNIFRA (2012). Master in Pharmaceutical Sciences from the Federal University of Santa Maria- UFSM (2016). Currently Doctoral student in Pharmaceutical Sciences UFSM.

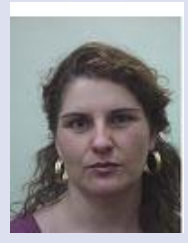

\section{Michele Rorato Sagrillo}

Email: sagrillomr@yahoo.com.br

Participation in geno and cytotoxicity assays. Graduated in Biological Sciences from the Federal University of Santa Maria (2000) and Master in Science - Genetics area, Federal University of São Paulo - Paulista School of Medicine, UNIFESP. PhD in Pharmacology - Pharmacogenomics area, Graduate Program in Pharmacology, Federal University of Santa Maria-RS. Adjunct Professor I at the Franciscan University, responsible for the disciplines of Medical Genetics and Human Genetics, also acting as a teacher / advisor in the Graduate Program in Nanosciences.

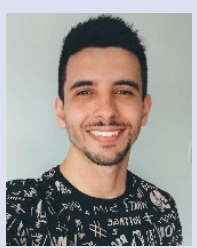

\section{Gerson Fernandes de Brum}

\section{Email: gersondebrum@hotmail.com}

Participation in geno and cytotoxicity assays. Degree in Biomedicine with qualification in Clinical Analysis and Molecular Biology from the Franciscan University (UFN-2017), Biomedical Technical Responsible for the Laboratory School of Clinical Analysis (LEAC) of UFN and Preceptor in the Multiprofessional Residency in Specialized Clinical Care of the same institution. Master student in the Graduate Program in Pharmacology, Federal University of Santa Maria (UFSM-2017). Has experience in clinical analysis, cell culture, cytotoxicity assays and research activities with laboratory animals.

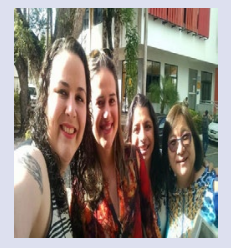

\section{Marli Matiko Anraku de Campos} Email: marlimatiko@yahoo.com

Advisor of this work. Full Professor at the Federal University of Santa Maria. Graduated in Biochemical Pharmacy from Paulista State University Júlio de Mesquita Filho - UNESP (1989), Master in Biological Sciences (Applied Microbiology) from Paulista State University Júlio de Mesquita Filho - UNESP (1995) and PhD in Pharmacy (Clinical Analysis) from the University of São Paulo. São Paulo - USP (2001). Has experience in Pharmacy, focusing on Clinical Microbiology and Clinical Parasitology, acting on the following subjects: plants with antimicobacterial activity, antimicobacterial compounds, antibiofilm compounds and Pharmaceutical Assistance. She is advisor in the Master / Doctorate in Pharmaceutical Sciences and Professional Master in Health Sciences at the Federal University of Santa Maria. 


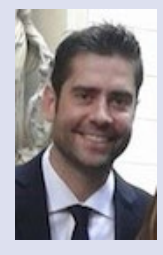

\section{Roberto Christ Vianna Santos} Email: robertochrist@gmail.com

Coordinator of this work. Graduated in Pharmacy-Clinical Analysis from PUCRS, specialization in Activation of Change Processes in Higher Education of Health Professionals from FIOCRUZ and master's degree in Biosciences from PUCRS. PhD in Cellular and Molecular Biology from PUCRS / Universitat de Barcelona and Postdoctoral from Universitat de Barcelona. He is currently an adjunct professor at the Department of Microbiology and Parasitology, Center for Health Sciences, Federal University of Santa Maria. Editor-inChief of Fungal Genomics and Biology. Ad-Hoc researcher of research projects at the National Agency of Recherche - French National Research Agency - France, National Agency for Scientific and Technological Promotion - FONCYT - Argentina and National Commission for Scientific and Technological Research CONICYT - Chile. Advisor (Master and Doctorate) in the Graduate Program in Pharmaceutical Sciences of UFSM and PPG-Nanosciences of UNIFRA.

Cite this article: dos Santos Alves CF, Bonez PC, de Souza Ebling M, Casagrande C, Freitas L, Dolwitsch C, et al. Antimicrobial, Cyto and Genotoxic Activities of Equisetum hyemale.Pharmacog J. 2019;11(6)Suppl:1563-71. 